\title{
Analysis of learning difficulties faced by first year students of STMIK Palangkaraya in English Subject as General Course
}

\author{
Catharina Elmayantie ${ }^{1}$, Norhayati ${ }^{2}$ \\ 1,2 STMIK Palangkaraya, Palangka Raya \\ 돈ainaelmayantie@gmail.com, 2 inoynorhayati@gmail.com,
}

\begin{abstract}
At the College of Informatics and Computer Management (STMIK) Palangkaraya, English course appear in the curriculum of each study programs. This course is divided into English I and English II, for both undergraduate and diploma levels. One of the goals of learning English here is so that students have the ability to speak English both verbally and in writing. The mastery level of English skill would be very beneficial for the students to comprehend their major subject; technology informatics and computers. As in the perspective of academic achievement for English courses, the students could be categorized at good level. As for the final assessment of a student, it is assessed by the level of attendance for each lecture, individual and group assignments, and test scores taken form midterm test and final test. One of the problem faced both teachers and students in teaching learning English that the lecturers have not been able to provide learning and assessment comprehensively for listening skill mastery. As the impact the students get less opportunity to practice listening skill. It is caused that the college does not yet have adequate supporting facilities such as language laboratory.
\end{abstract}

\section{INTRODUCTION}

In learning English, the achievements of STMIK Palangkaraya students could be seen based on the record scores of each student which were obtained from the results of learning evaluations in the form of individual and group assignments, mid-semester exams, and end-semester exams. From the results of these evaluations, it could be seen that some students have not achieved the excellent criteria in learning English. Based on previous observations at the beginning of the semester, it was found that most the students had low level of English proficiency. For example, the students found difficulties in following and understanding instructions and expressions with simple vocabularies. In the next learning stage, it was found that the problem for most of the students had weakness in mastery of the four language competencies, they are: listening, speaking, reading, and writing. 
Learning is a process that aims to change a person, including the behavior, attitudes, habits, knowledge, skills, or an understanding through experiences so that they become more advanced. According to Darsono in Setya (2009, p. 22), learning is an activity that involves the individual as a whole, both physically and psychologically, to achieve the goal.

According to Rifa'i and Anni in Kurniawan (2015, p. 10), learning theory is an attempt to describe how human beings and animals learn so as to help us understand the inherently complex process of learning. There are four main categories or philosophical frameworks regarding learning theories, they are: neo behaviorism learning theory, cognitive learning theory and constructivism learning theory, humanistic learning theory.

Factors that affect learning can come from various factors. The factors that influence learning can be divided into two, they are: internal factors and external factors. Sukirin $(1979$, p. 64) stated that internal factors are related to student factors and external factors are related to factors outside students. Those internal factors are; 1) health conditions, 2) talent, 3) interest, 4) motivation. Dalyono (2005, p. 235) stated that motivation is an inner factor that functions to generate, underlie, and direct the act of learning. Motivation can determine in achieving goals so that the greater the motivation, the greater the learning success.

\section{METHODS}

The method used in this study was qualitative descriptive method in which the authors produce descriptive data in the form of written or spoken words from the people or actors observed at the time of the study. The methods that used in collecting data were observations, direct interviews, and giving questionnaire to the participants. Several data obtained from observations, interviews and written documentation.

\subsection{Subject of the study}

The subjects in this study were students of STMIK Palangkaraya Informatics Engineering Study Program class A and Class B for the academic year 2020/2021. 


\subsection{Place of the study}

This study had been carried out at the College of Informatics and Computer Management (STMIK) Palangkaraya.

\subsection{Data collecting method and instruments used}

The basic methods used by qualitative researchers to collect data were participation in setting, direct observation, in-depth interviews, and documentation (Sugiyono, 2013, p. 309). In this study, the authors conducted direct observations, interviews with research subjects, as well as collecting documents related to research.

In the observation stage, the authors recorded various things that were found related to the research; what difficulties were encountered in learning English by the research subjects.

The interview method is a way of collecting data or information by asking a number of questions orally to research subjects to obtain answers orally as well. This method was used to collect data about the description of the object of research, especially those related to the difficulties faced by students in learning English.

Documentation is the retrieval of data obtained from certain documents that support research, including student data, data on student learning outcomes in English courses, and other relevant documents.

\subsection{Technical data analysis}

After all the information was collected, the writer processes and analyzes all the information obtained. In detail, data analysis was carried out through 3 (three) stages, they were;

\section{Data Reduction}

In the data reduction stage, the authors choose data that was relevant to the research. In this case, the author would sort out the data needed or according to the focus of the study to obtain answers to the problem formulation that was previously determined.

2. Data Presentation 
All data obtained in the form of field notes, author responses and documents are arranged, sorted, grouped, coded and categorized according to data groups systematically. The presentation of the data would be in the form of a narrative or presentation.

\section{Conclusion Drawing or Data Verification}

Conclusions or verification of data related to the difficulty of achieving English learning by STMIK Palangkaraya students and their causal factors was carried out after the data was analyzed continuously during data collection, both in the field, in the process and after completion in the field.

\subsection{Research Procedure}

The research procedure that was implemented as followed

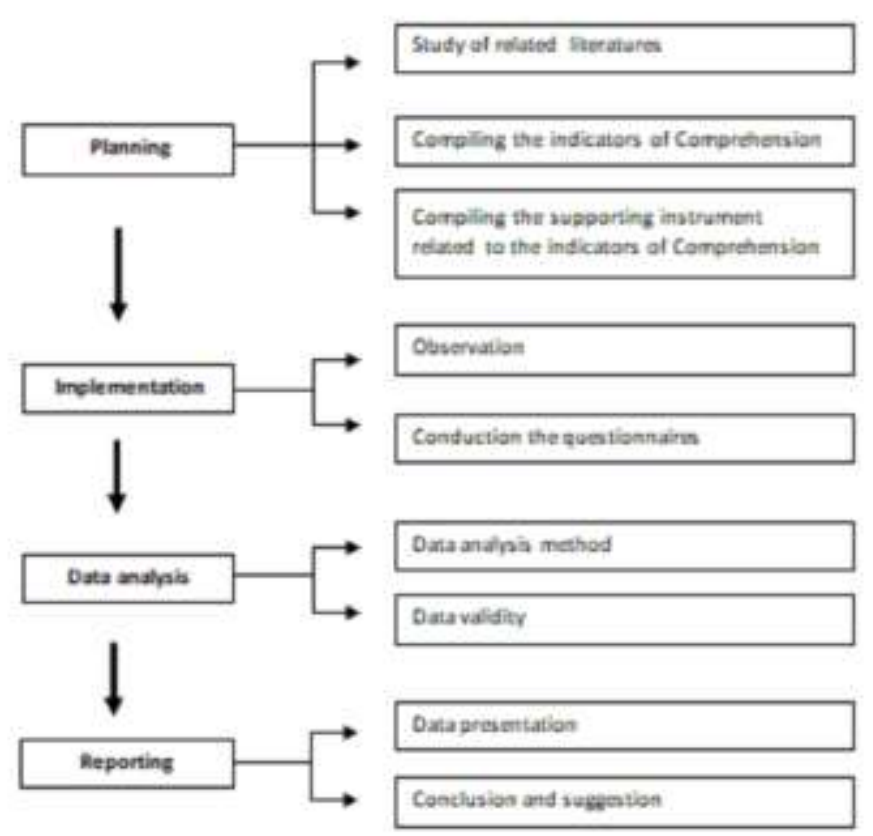

Figure 1. Diagram Caption Research Flowchart.

\section{RESULTS AND DISCUSSION}

Questionnaires were given to STMIK Palangkaraya students with a random sampling system. The questionnaire was made in accordance with the flow of questions so that 
researchers could find out how far the learning process and students' interest in English lessons were.

The research subjects were assigned only to students, because the method used random sampling, so the researchers only took a sample of 60 students, especially students who were taking English II courses in the Department of Informatics Engineering class A and B in the even semester of the 2020/2021 academic year.

3.1. Analysis of the difficulties faced by STMIK Palangkaraya students in learning English

Academic ability is one of the factors that influence student learning outcomes. Students' academic ability is a description of their level of knowledge or ability towards a learning material that has been studied. As an illustration of a student's academic ability, it is usually photographed using grades or numbers as an index of students' achivement.

Table 1 Percentage of respondents' passing scores for English courses

\begin{tabular}{|c|c|}
\hline Final Score & $\%$ \\
\hline A & $31,67 \%$ \\
\hline B & $63,33 \%$ \\
\hline C & $3,33 \%$ \\
\hline D & $1,67 \%$ \\
\hline
\end{tabular}

Based on the data above, from 60 respondents it was known that there were $31.67 \%$ of respondents whose final grades in English courses get A grade, B grade of $63.33 \%$, while those who get $C$ grade are $3.33 \%$, and $D$ grade was $1,67 \%$.

Most of the respondents already have a good base of English, but still they needed to develop and got used to continue to develop their English skills. Language skills are not only the ability to master the theory, but the most important thing is the ability to communicate properly and correctly in using the language. 


\subsection{Student Interest in English Courses}

According to Kamus Besar Bahasa Indonesia, interest is defined as a high inclination towards something; excitement; desire. Language is not only memorizing but must be practiced often. Someone who has an interest in language would tend to use it often in everyday life. As a student, his interest and desire to be able to master English would be judged by how serious he is in learning the language. The level of attendance at the time of the course and completing assignments and being active in language study club activities are indicators of a student's interest in mastering English.

Table 2 The percentage of final grades compared to the respondent's attendance rate for English courses

\begin{tabular}{|c|c|}
\hline Final Score & Attendance Average \\
\hline A & $94,64 \%$ \\
\hline B & $94,17 \%$ \\
\hline C & $97,28 \%$ \\
\hline D & $71,43 \%$ \\
\hline
\end{tabular}

The percentage of respondents' attendance for English courses is very high, except for respondents who get a final grade of $D$, which is only $71.43 \%$. This shows that students' interest in learning English is very good, for that it needs to be given appreciation; this good interest needs to be given a stimulus so that it could develop, and students not only like English because of the final grade factor, but need to be encouraged to master English, both passive and active.

STMIK Palangkaraya suggested facilitating the English-based student activities, such as the existence of an English Club or the establishment of a language Technical Implementation Unit (UPT). By the support of the language lab, it is expected that it could improve students' ability to master English and this at the same time could improve campus academic achievement.

In addition to the level of attendance, researchers also need to measure how high the respondent's interest in English courses is. Related to that idea, the writer provided some questions related to the students' interest have in English courses. 
Table 3 questionnaires related to the description of how interested students are in English courses.

\begin{tabular}{|l|c|c|c|}
\hline \multicolumn{1}{|c|}{ Statements } & Always & Sometimes & Never \\
\hline I feel happy learning English. & $83 \%$ & $17 \%$ & $0 \%$ \\
\hline $\begin{array}{l}\text { I pay attention to all the explanations given } \\
\text { by the lecturer when the learning takes place. }\end{array}$ & $30 \%$ & $70 \%$ & $0 \%$ \\
\hline $\begin{array}{l}\text { I answer every question posed by the } \\
\text { lecturer. }\end{array}$ & $32 \%$ & $65 \%$ & $3 \%$ \\
\hline $\begin{array}{l}\text { I only do the exercises given by the lecturer. } \\
\begin{array}{l}\text { If I encountered some difficulties in doing } \\
\text { exercises, then the exercises would not be } \\
\text { done. }\end{array}\end{array}$ & $2 \%$ & $22 \%$ & $77 \%$ \\
\hline $\begin{array}{l}\text { When it comes to English exams, I try hard to } \\
\text { get the best results. }\end{array}$ & $90 \%$ & $7 \%$ & $3 \%$ \\
\hline
\end{tabular}

From the table data above, it could be seen that $83 \%$ of respondents answered that they were very happy with English, only $17 \%$ answered sometimes. Respondents are very enthusiastic to learn English. This was indicated by none of the respondents who never paid attention to any explanation given by the lecturer when the learning took place, although there were still $70 \%$ of respondents who answered sometimes. This may be due to several factors, among others, due to an unsupportive class atmosphere such as there was a noise when the lecturer explained, there were friends who invited to chat, the hot weather caused a lack of focus, and it could also be due to drowsiness and hunger because the lecture hours were during the day. When the lecturer asked a question, only $3 \%$ of the respondents never answered, while $32 \%$ said that they could always answer, and $65 \%$ of the respondents answered that they could sometimes answer. Only $2 \%$ of respondents said that they had never done the questions given by the lecturer, while $88 \%$ of respondents answered that they always did and $10 \%$ answered that they were sometimes done.

For difficult questions, the majority of respondents, they are; $77 \%$ said that they would keep working, and only $2 \%$ said that they had never done it, while the remaining $22 \%$ of respondents answered that they sometimes did it. As a form of happiness and responsibility as students, $90 \%$ of respondents answered that they would struggle and work hard to get the best score when the exam is held. For that 
they must focus and study hard, and only $3 \%$ are lazy, while the remaining $7 \%$ answer sometimes depending on mood, situation and condition.

Happiness is the beginning of one's love for something; happiness is strongly influenced by one's emotions and perceptions of something. There are many factors that influence respondents so that they feel happy about English courses, among others because the lecturers are good, friendly and fun, the delivery method is good and easy to catch, and even they really want to master English because they feel it is very necessary to support their discipline, in the field of information technology. In general, the feeling of happiness is related to perception, and is a reaction to the stimulus that hits it and is very subjective.

\subsection{Student Perception of English Course}

Each individual has a tendency to always give meaning to the stimuli he receives with his knowledge and experience, which then the individual responds to the stimuli he receives, the individual's ability to respond to the stimuli he receives is called the ability to perceive. According to Moh. Surya (1981: 41) Perception is the process of receiving, interpreting and giving meaning to stimuli received by individuals through the senses.

Meanwhile, McCroskey and Whelness (in Ritonga, 1998: 15) state that there are four stages of perception:

1. Receiving messages or information from outside.

2. Provide a code on the information that is sensed.

3. Interpret the information given by the code.

4. Infer meaning in memory.

Perception is closely related to the five human senses, every experience and knowledge that we have ever felt in the past would be embedded in our memory which makes our benchmark and assessment of something happening now and in the future. A student's perception of the form and pattern of teaching English is formed from his past experiences from elementary to high school levels. 
A pleasant experience would form a positive perception and vice versa a bad experience would create a negative perception. Students who have a positive perception would be very enthusiastic to attend lectures and vice versa those who are negative would consider themselves incapable and lazy to attend lectures. Researchers tried to ask some questions to see the picture of respondents' perceptions of English courses.

Table 4 Respondents' perceptions of English courses

\begin{tabular}{|l|c|c|c|}
\hline \multicolumn{1}{|c|}{ Statement } & Always & Sometimes & Never \\
\hline $\begin{array}{l}\text { I feel scared and anxious when learning } \\
\text { English. }\end{array}$ & $85 \%$ & $13 \%$ & $2 \%$ \\
\hline $\begin{array}{l}\text { I am afraid to ask the lecturer if there is } \\
\text { material that is not clear. }\end{array}$ & $62 \%$ & $37 \%$ & $2 \%$ \\
\hline $\begin{array}{l}\text { I ask my friends if they have difficulty with } \\
\text { questions or do not understand the } \\
\text { material taught by the lecturer. }\end{array}$ & $58 \%$ & $40 \%$ & $2 \%$ \\
\hline $\begin{array}{l}\text { I am happy and passionate about doing } \\
\text { homework and assignments given by the } \\
\text { lecturer. }\end{array}$ & $57 \%$ & $42 \%$ & $2 \%$ \\
\hline $\begin{array}{l}\text { I like to find English material questions and } \\
\text { solve them apart from textbooks/modules. }\end{array}$ & $12 \%$ & $62 \%$ & $27 \%$ \\
\hline $\begin{array}{l}\text { When the lecturer explained in front of the } \\
\text { class, I joked and chatted with friends. }\end{array}$ & $20 \%$ & $78 \%$ & $2 \%$ \\
\hline $\begin{array}{l}\text { At home I first study the material that } \\
\text { would be taught by the lecturer. }\end{array}$ & $7 \%$ & $77 \%$ & $17 \%$ \\
\hline $\begin{array}{l}\text { I study English material only if there is an } \\
\text { exam }\end{array}$ & $28 \%$ & $53 \%$ & $18 \%$ \\
\hline $\begin{array}{l}\text { I work on assignments only when they have } \\
\text { to be submitted. }\end{array}$ & $38 \%$ & $28 \%$ & $33 \%$ \\
\hline
\end{tabular}

Most of the respondents or $85 \%$ of respondents stated that they felt afraid and anxious when learning English. This fear and anxiety is caused by feeling insecure. This feeling of insecurity makes them afraid to try to speak using the target language, afraid of being wrong and afraid of being laughed at by others. There are at least five reasons why someone is not confident:

1. Negative Prejudice

Perception is built on the power of the mind; a person who has had a bad experience in the past would always have a negative attitude every time he 
experiences an incident or faces the same problem as his past. Based on the table data above, most of the respondents or $62 \%$, answered that they were afraid to ask questions, even though they did not understand the material being taught, they preferred to ask their fellow students for things they thought they did not understand. The existence of fear and anxiety every time they would take English lessons, or being afraid to ask if something is not understood, or fear of being asked by the lecturer is an attitude that is built based on past experiences, there is a fear of being blamed and laughed at by the lecturer and his colleagues.

2. Don't recognize the potential in their selves

Those who do not believe in themselves are those who have not found their strength. This is because some of them are more focused on their weaknesses. In fact, they always compare the strengths of others with their weaknesses. People who never get appreciation by the surrounding environment would feel inferior, feel unable and feel always defeated. In contrast to people who have achievements and always get attention from the environment around them, they would have high selfconfidence, because they feel they have potential and achievements compared to other people. Someone who has achievements always asks to be noticed and appreciated for every effort he makes, and vice versa, those who feel that they are not achieving are usually embarrassed to be able to show their potential.

3. Do not have knowledge or experience

Lack of confidence sometimes arises as a result of not mastering the field to be worked on. Unlike the case with someone who feels he already has the experience and knowledge of the problem, he would have high confidence to be able to solve the problem. An active student, who always completes the assignments given by the lecturer, has complete lecture materials and always listens to every material given by the lecturer would have more confidence than passive students. A student who has studied and mastered the material would be very confident in facing the exam, on the other hand those who do not study and do not master the material would not be confident in taking the exam, so that many negative things are done, such as cheating on friends' answers, or exam questions are not done at all. do not try hard to solve 
the exam questions because they feel that they are unable as a result of not preparing themselves beforehand.

4. Being in the wrong place and at the wrong time

A person would have a level of self-confidence when he is in the midst of the same community, in an environment where people feel in the same boat, help each other and strengthen each other when facing a problem. On the other hand, if his environment is often bullying, sarcastic, criticizing a lot without a solution when he encounters failure, it would make him have a sense of fear and anxiety every time he does something. The establishment of the English Club is a form of solution to create a forum for students who have the same interest to help each other in learning. This club would be filled with people who have interests and talents who both want to learn English and would help each other for their colleagues who still have a shortage in learning English.

\section{Not having closeness}

Someone who feels he has support would have confidence because he feels that someone would protect him. A student who feels familiar and close to his lecturer would feel comfortable every time he takes a course taught by the lecturer, he would feel more confident, not afraid to ask questions and not afraid to be blamed, a lecturer should act as a protector so that every student feels comfortable, is not afraid of being bullied, and is laughed at by his friends when he makes a mistake.

\subsection{Factors Causing Difficulty in Learning English for STMIK Palangkaraya Students}

There are many factors that cause a person to have difficulty learning English. Here the author describes some of the most dominant problems experienced by STMIK Palangkaraya students in learning English, including:

- Pronunciation

This is what many people always complain about, and this is what makes many people say English is Crazy Language. Indonesian people have been very get used to the pronunciation as it is written. And it turns out that there are no very standard rules for how to pronounce foreign language words. For some people, English is a 
difficult language because English vocabulary is difficult to pronounce. As you know, some letters like $r$ or $t$ are implicit in English and require a certain way to pronounce them. Many feel hesitant to speak English for fear of pronouncing it wrong. Speaking in English is an important thing to do to improve English language skills. So obstacles like this would definitely hinder the ability to understand English more deeply. Some of the obstacles that are often found in learning conversational English are:

1. Pronunciation is different from writing

2. Sounds the same but has a different meaning

3. Could speak fluently but couldn't write because they don't know or forget.

- Vocabulary Mastery

In addition to pronunciation, vocabulary in English is also an obstacle in learning. Vocabulary in English is so diverse. Some look the same but have different meanings and pronunciations. There are so many vocabularies, some people feel overwhelmed when they have to memorize them. Even vocabulary in English often has different functions. For example the words "have" which could be used to express ownership and is also a complement to some tenses. For the students who are not very proficient in English, of course it becomes an obstacle and often makes them confused. Finally, gradually these obstacles make them feel lazy to explore it.

Some of the obstacles that often arise in learning English vocabulary are:

1. Difficult to remember words

2. Unable to distinguish nouns from verbs or others

3. Must memorize a lot of tenses

- $\quad$ Listening

Listening is a complex process that allows the brain to construct meaning from the sounds it hears and understand language.

This ability is greatly influenced by mastery of vocabulary, pronunciation and also the meaning of words or sentences. There are several obstacles that are often encountered in learning listening, they are;:

1. Lack of mastery of pronunciation

2. Less vocabulary 
3. Rarely speak the target language

4. Rarely listens to conversations in the target language.

\section{CONCLUSIONS}

The process of learning English could not be separated from the emergence of various difficulties that occur, especially for students. These difficulties could be seen from each language skill or as a whole. In class conditions that have different language competencies, the difficulties faced also vary in results. In this study, the research subjects showed difficulties in learning English in pronunciation, vocabulary mastery and listening.

In terms of academic achievement for English courses, STMIK Palangkaraya students could already be categorized as good. For the final assessment, a student would be assessed from the level of attendance for each lecture, individual and group assignments, and test scores. The drawback at STMIK Palangkaraya is that the lecturers have not been able to provide learning and assessment for maximum listening mastery because the campus does not yet have more adequate supporting facilities such as a language laboratory.

\section{REFERENCES}

Arnanda, N., \& Harpain. (2017). An Analysis of Students' Difficulties in Speaking English at Grade X of SMA Persada Bandar Lampung. Jurnal Linguistika vol.8 no.2. http://jurnal.ubl.ac.id/index.php/Linguistika/article/view/1384

Arikunto, Suharsimi. (2010). Manajemen Penelitian. Jakarta: PT. Rineka Cipta.

Bogdan, Robert. (1998). Qualitative Research for Education : An Introduction to Theory and Methods. The Third Edition. United States of America : A Viacom Company.

Brown, H.Douglas. (2001). Teaching by Principles : An Interactive Approach to Language Pedagogy. Second Edition. New York : Addison Wesley Longman, Inc.

Dalyono, M. (2005). Psikologi Pendidikan. Jakarta: Rineka Cipta

Hamid, Darmadi. (2013). Metode Penelitian Pendidikan dan Sosial. Bandung:

Alfabeta

Hasbullah. (2013). Dasar-dasar ilmu pendidikan. Jakarta: Rajawali Press 
Kurniawan, Zuhrian Hendra. (2015). Faktor Penyebab Kesulitan Bahasa Jepang Siswa SMA Negeri 15 Semarang. Skripsi. Program Studi Bahasa Jepang Fakultas Bahasa dan Seni Universitas Negeri Semarang

Marshall, Catherine. (1995). Designing Qualitative Research. Second Edition. California: SAGE Publications,Inc.

Moleong, J. Lexy. (2000). Metode Penelitian Kualitatif. Bandung: PT. Remaja Rosda Karya.

Raharjo, Mudjia. (2002). Pengantar Penelitian Bahasa. Malang : Cendekia Paramulya.

Richards, Jack C. (2001). Curriculum and Materials Development for English Teaching. Cambridge: Cambridge University Press.

Setiyadi, Bambang,dkk (-------) . TEFL II. Modul Edisi Kedua. Pusat Penerbitan Universitas Terbuka.

Setya, Andresta. (2009). Faktor- faktor yang Mempengaruhi Kesulitan Belajar Mat Pelajaran Teknologi Informasi dan Komunikasi Siswa Kelas VII Semester I SMP Islam Hidayatullah Semarang. Skripsi. Jurusan Manajemen Fakultas Eknonomi Universitas Negeri Semarang.

Slameto. (2013). Belajar dan Faktor-Faktor Yang Mempengaruhinya. Jakarta: Rineka Cipta

Sudjono, Anas. (2015). Pengantar Evaluasi Pendidikan. Jakarta: Rajawali Press

Sukirin. (1979). Pokok- Pokok Psikologi Pendidikan. Yogyakarta: FIP IKIP Yogyakarta

Sundari, W. (2018). The Difficulties of Learning English for the Beginner English Learners. Culturalistics: Journal of Cultural, Literary, and Linguistics Studies, 2(1), https://ejournal2.undip.ac.id/index.php/culturalistics/article/ view/2050

Sugiyono. (2013). Metode Penelitian Kuantitatif Kualitataif Dan R\&D. Bandung: Alfabeta.

Syah, M. (2010). Psikologi Pendidikan Dengan Pendekatan Baru. Bandung: PT Remaja Rosdakarya.

Tarigan, Henry Guntur. (2015). Menyimak Sebagai Suatu Keterampilan Berbahasa. Bandung : Angkasa.

Turner, L. (2000). Metodologi Pengajaran Bahasa B: Study Guide. Deakin University, Geelong, Vic. 